\title{
ANALISIS DOKUMEN REKAM MEDIS RAWAT INAP KASUS BEDAH DI RUMAH SAKIT X BANDUNG
}

\author{
Siti Khofidhoh ${ }^{1 *}$, Meira Hidayati ${ }^{2}$ \\ Politeknik Piksi Ganesha Bandung, Indonesia ${ }^{1,2}$ \\ skhofidhoh@piksil.ac.id ${ }^{1 *}$, meira.hidayati@piksi.ac.id ${ }^{2}$
}

Received: 05-08-2021

Revised : 20-10-2021

Accepted: 24-10-2021

\begin{abstract}
Abstrak
Latar Belakang: Instansi pelayanan kesehatan harus selalu meningkatkan mutu pelayanan kesehatan dengan menyelenggarakan rekam medis yang cepat, tepat dan akurat. Kelengkapan data rekam medis dapat di review pada empat yaitu review identifikasi, autentifikasi, pencatatan dan pelaporan.
\end{abstract}

Tujuan: Penelitian ini bertujuan untuk mengetahui angka kelengkapan dokumen rekam medis rawat inap kasus bedah di Rumah Sakit X Bandung dengan analisis kuantitatif.

Metode: Penelitian ini menggunakan pendekatan deskriptif kuantitatif. Pengambilan sampel menggunakan rumus Slovin dengan populasi 190 dan hasil sampel yang didapatkan adalah 65 sampel.

Hasil: Hasil penelitian ini didapatkan review kelengkapan berdasarkan identifikasi pasien yaitu $61 \%$ dan review ketidaklengkapannya yaitu 39\%. Hasil review pada kelengkapan pelaporan yang penting yaitu $45 \%$ dan ketidaklengkapannya yaitu 55\%. Hasil review kelengkapan pada autentifikasi yaitu $75 \%$ dan ketidaklengkapannya yaitu $25 \%$. Hasil review kelengkapan pada dokumentasi yaitu $63 \%$ dan ketidaklengkapannya yaitu $37 \%$.

Kesimpulan: Bahwa dokumen rekam medis yang tidak lengkap setelah di KLPCM dan dianalisis kelengkapannya akan dikembalikan kepada unit rawat inap. Saran yang disampaikan yaitu perlu dilakukan sosialisasi ulang kepada seluruh tenaga kesehatan (dokter dan perawat) tentang Standar Prosedur Operasional (SPO) pengisian atau pencatatan resume medis agar tercapainya standar pelayanan minimal dengan hasil $100 \%$.

Kata kunci: Analisis Kuantitatif; Dokumen Rekam Medis; Kasus Bedah.

\begin{abstract}
Background: Health service agencies must always improve the quality of health services by organizing medical records that are fast, precise, and accurate. Completeness of medical record data can be reviewed in four, namely review identification, authentication, recording, and reporting.

Objective: This study aims to determine the number of completeness of medical record documents for inpatient
\end{abstract}




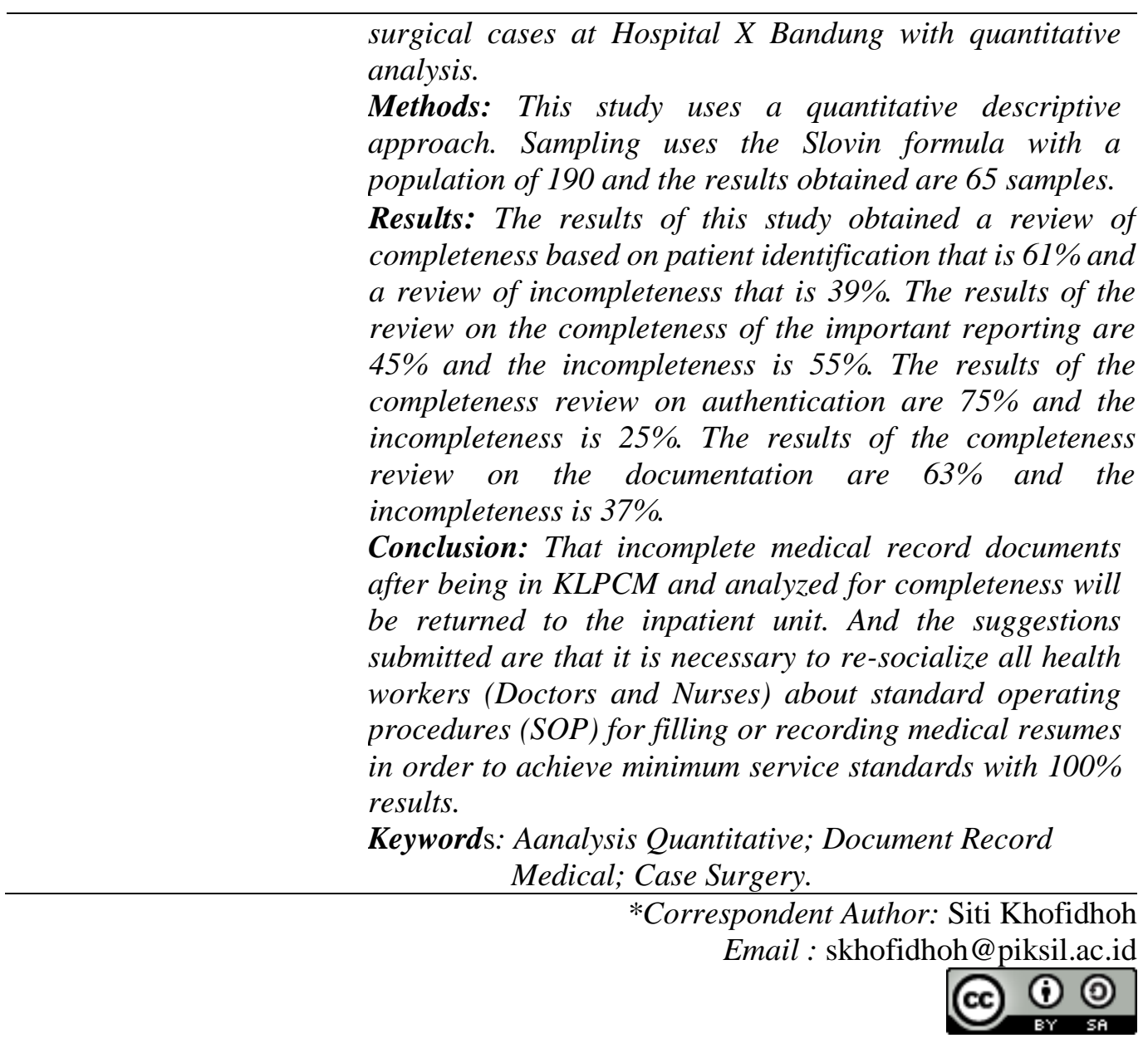

\section{PENDAHULUAN}

Rumah Sakit adalah institusi pelayanan kesehatan bagi masyarakat dengan karakteristik tersendiri yang dipengaruhi oleh perkembangan ilmu pengetahuan kesehatan, kemajuan teknologi dan kehidupan sosial ekonomi masyarakat yang harus tetap mampu meningkatkan pelayanan yang lebih bermutu dan terjangkau oleh masyarakat agar terwujud derajat kesehatan yang setinggi-tingginya (Arini et al., 2015).

Kelengkapan dalam pengisian berkas rekam medis oleh dokter akan dapat memudahkan tenaga kesehatan lain dalam memberikan tindakan atau pengobatan pada pasien, dan dapat dijadikan sebagai sumber data pada bagian rekam medis dalam pengelolaan data dan laporan yang akan dijadikan informasi yang berguna bagi pihak manajemen rumah sakit dalam menentukan evaluasi dan pengembangan pelayanan kesehatan (Hatta, 2013).

Instansi pelayanan kesehatan harus selalu meningkatkan mutu pelayanan kesehatan, salah satunya adalah dengan menyelenggarakan rekam medis yang cepat, tepat, dan akurat (Susanto \& Windari, 2017). Sesuai dengan Permenkes RI Nomor 269/MenKes/Per/III/2008 tentang rekam medis adalah berkas yang berisikan catatan dan dokumen tentang identitas pasien, pemeriksaan, pengobatan, tindakan dan pelayanan lain yang telah diberikan kepada pasien. Penilaian dokumen rekam medis dapat dilakukan dengan cara analisis kuantitatif (Permenkes, 2008a).

Rekam medis menurut para ahli yaitu : 1) Menurut Undang-Undang No.29 tahun 2004 pasal 46 ayat (1) tentang praktik kedokteran, rekam medis adalah berkas yang berisikan catatan dan dokumen tentang identitas pasien, pemeriksaan pengobatan, tindakan 
dan pelayanan lain yang telah diberikan kepada pasien (UU No. 29 Tahun 2004 Tentang Praktik Kedokteran, 2004). 2) Menurut (Munawaroh et al., 2013) rekam medis adalah kumpulan keterangan tentang identitas, hasil anamnesis, pemeriksaan dan catatan segala kegiatan para pelayan kesehatan atas pasien dari waktu ke waktu.

Berdasarkan laporan hasil kegiatan yang didapatkan bahwa jumlah kasus bedah di Rumah Sakit X Bandung pada bulan Maret 2021 itu lebih tinggi (190) kasus dibandingkan bulan-bulan sebelumnya. Peningkatan kasus bedah dari bulan sebelumnya itu naik $36 \%$. Dalam penelitian ini akan dianalisis kelengkapan resume medis di Rumah Sakit X Bandung karena persentase kelengkapannya masih belum optimal dimana masih banyak resume medis yang belum terisi dengan lengkap. Sesuai dengan standar pelayanan minimal mutu rekam medis kelengkapan pengisisan resume medis harus $100 \%$ (Permenkes, 2008).

Berdasarkan studi pendahuluan yang dilakukan oleh (Esraida Simanjuntak, 2016) pada berkas rekam medis khususnya kasus bedah masih belum terisi yaitu sebanyak $40 \%$ dari semua kasus bedah yang ada di RSU IPI Medan. Hal ini disebabkan karena kurangnya kesadaran petugas untuk melengkapi berkas rekam medis dengan baik, Setiap petugas harusnya menyadari akan pentingnya kelengkapan dokumen rekam medis.

Setiap komponen pada review pencatatan dilakukan skoring dan di kategorikan menjadi dua yaitu lengkap dan tidak lengkap. Lengkap yaitu kondisi dimana komponen pencatatan terisi. Tidak lengkap yaitu kondisi dimana komponen pencatatan tidak diisi sesuai cara pencatatan. (Marsum, Elisa dkk. 2018)

Mengenai kelengkapan dalam pengisian dokumen rekam medis rawat inap kasus bedah di Rumah Sakit X Bandung sejumlah 65 dokumen dengan persentase kelengkapan yang belum optimal yaitu pengisian Identifikasi pasien $61 \%$, catatan yang penting $45 \%$, autentifikasi 75\%, pendokumentasian 63\% (Septiany, 2020). dari kelengkapan yang belum sesuai dengan standar playanan minimal yang bisa berakibat tertundanya pelaporan dan jika ada pasien yang meminta dibuatkan surat keterangan medis prosesnya bisa tertunda karena harus meminta dokter untuk melengkapi dokumen rekam medis tersebut.

Tujuan pada penelitian ini yaitu: 1). Untuk mengetahui proses dilaksanakannya analisis pada dokumen rekam medis rawat inap kasus bedah di Rumah Sakit X Bandung. 2).Mengetahui hasil analisis dokumen rawat inap kasus bedah di Rumah Sakit $X$ Bandung. 3).Mengetahui faktor penyebab ketidak lengkapan pengisian dokumen rekam medis rawat inap kasus bedah di Rumah Sakit X Bandung.

\section{METODE PENELITIAN}

Penelitian ini dilakukan dan bertempat di Rumah Sakit X Bandung khususnya di Instalasi Rekam Medis unit KLPCM. Waktu penelitian ini berlangsung pada tanggal 5 April hingga 5 juni 2021. Penelitian yang digunakan yaitu pendekatan deskriptif kuantitatif dengan tujuan untuk mengetahui hasil kelengkapan dokumen rekam medis rawat inap kasus bedah di Rumah Sakit X Bandung.

Cara pengumpulan data pada penelitian ini dengan metode observasi dan wawancara. Metode ini digunakan untuk mengetahui kelengkapan pengisian dokumen rekam medis rawat inap kasus bedah dan melakukan pengamatan secara langsung pada formulir rekam medis rawat inap kasus bedah di Rumah Sakit X Bandung.

Analisis yang digunakan dalam penelitian ini adalah analisis deskriptif. Teknik yang digunakan dalam penelitian ini yaitu dengan cara mendeskripsikan data yang telah dikumpulkan dan diolah sebagai evaluasi untuk membuat gambaran tentang analisis kuantitatif dokumen rekam medis rawat inap kasus bedah di Rumah Sakit X Bandung

Populasi adalah sebagian wilayah generalisasi terdiri dari objek/subjek yang memiliki kualitas dan karakteristik tertentu untuk dipelajari lalu diambil kesimpulannya

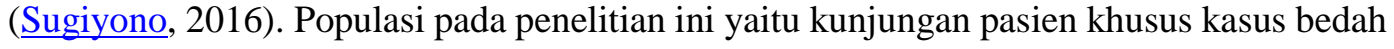


selama 1 bulan pada bulan Maret 2021 di Rumah Sakit X Bandung berjumlah 190. Sampel adalah jumlah dan karakteristik yang dimiliki oleh populasi. Sampel dalam penelitian ini adalah dokumen rekam medis pasien awat inap kasus bedah periode bulan Maret 2021.

Cara menghitung jumlah sampel menggunakan rumus Slovin sebagai berikut :

$n=\frac{N}{1+N e^{2}}$

Keterangan :

$n=$ Jumlah sampel

$N=$ Jumlah populasi (populasi pada bulan Maret $=190$ )

$e=$ Presisi yang ditetapkan $(10 \%=0,1)$

$\mathrm{n}=\frac{190}{1+190(0,1)^{2}}=\frac{190}{1+1,9}=\frac{190}{2,9}=65,51=65$

\section{HASIL DAN PEMBAHASAN}

\section{A. Hasil Penelitian}

Cara menganilis dokumen rekam medis ini dengan form observasi analisis kuantitatif pada dokumen rekam medis kasus bedah bulan Maret 2021 di unit rekam medis Rumah Sakit X Bandung. adapun penjelasannya jika hasil : 0 (nol) = tidak lengkap, 1 (satu) = lengkap. Penilaian angka 0 diberikan jika dokumen rekam medis tidak lengkap, dan penilaian angka 1 diberikan jika dokumen rekam medis lengkap. selanjutnya nilai ditabulasi menggunakan rumus persentase tabulasi :

Tabulasi $=\frac{\text { Jumlah Nilai }}{\sum \text { Sampel }} \times 100 \%$

Keterangan :

Tabulasi : Perhitungan nilai hasil review.

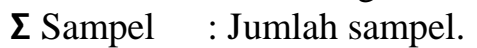

1. Review Identifikasi Pasien

Analisis dimulai dengan memeriksa setiap formulir rekam medis dan kriteria yang dinilai pada review identifikasi pasien adalah nama dan nomor rekam medis. Setelah itu hasil di tabulasi berdasarkan rumus tabulasi yang telah ditentukan. Berikut tabel peilaian analisis berdasarkan review identifikasi pasien :

Tabel 1. Review Identifikasi Pasien

\begin{tabular}{clcc}
\hline \multirow{2}{*}{ No. } & \multirow{2}{*}{ Kriteria } & \multicolumn{2}{c}{ Kelengkapan } \\
\cline { 3 - 4 } & & L & TL \\
\hline 1. & Nama Pasien & 39 & 26 \\
\hline 2. & Nomor Rekam Medis & 41 & 24 \\
\hline & Rata-rata & 40 & 25 \\
\hline
\end{tabular}

Berdasarkan tabel 1, hasil kelengkapan yang di dapatkan dari pengisian nama pasien sebanyak 39 dokumen dan ketidaklengkapannya sebanyak 26 dokumen. Dan hasil kelengkapan nomor rekam medis sebanyak 41 dokumen dan ketidaklengkapannya 
sebanyak 24 dokumen. Dari hasil rata-rata yang didapatkan pada hasil kelengkapan di atas berjumlah 40 dokumen dan ketidaklengkapannya berjumlah 25 dokumen.

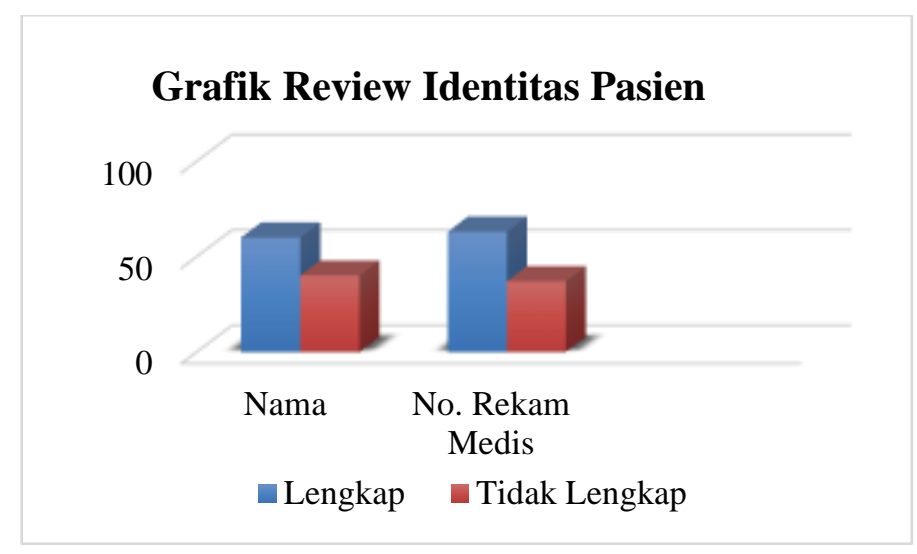

Gambar 1. Grafik Review Identitas Pasien

Berdasarkan gambar 1, grafik menjelaskan bahwa adanya hasil persentase pada identifikasi pasien dengan persentase kelengkapan penulisan nama pada dokumen rekam medis sebesar (60\%) dan ketidaklengkapannya (40\%). Persentase kelengkapan penulisan nomor rekam medis sebesar $(63 \%)$ dan ketidaklengkapannya (37\%). Dari hasil diatas bahwa persentase belum $100 \%$ untuk memenuhi standar pelayanan minimal di rumah sakit.

2. Review Pelaporan yang Penting

Kriteria yang di nilai pada review pelaporan yang penting yaitu lembar ringkas masuk dan keluar, diagnosa masuk, diagnosa utama, kode ICD-10, lembar ringkasan keperawatan, lembar laporan anastesi, lembar laporan operasi, tindakan operasi, kode tindakan ICD-9-CM dan lembar informed consent. Setelah dokumen rekam medis di analisis, selanjutnya hasil ditabulasi berdasarkan rumus tabulasi yang sudah ditentukan. Adapun hasil perhitungan pada review pelaporan yang penting sebagai berikut :

Tabel 2. Review Pelaporan yang Penting

\begin{tabular}{clcc}
\hline \multirow{2}{*}{ No. } & \multicolumn{2}{c}{ Kriteria } & \multicolumn{2}{c}{ Kelengkapan } \\
\cline { 3 - 4 } & & L & TL \\
\hline 1. & Ringkas Masuk dan Keluar & 28 & 37 \\
\hline 2. & Diagnosa Masuk & 65 & 0 \\
\hline 3. & Diagnosa Utama & 25 & 40 \\
\hline 4. & Kode ICD-10 & 20 & 45 \\
\hline 5. & Ringkasan Keperawatan & 33 & 32 \\
\hline 6. & Laporan Anastesi & 25 & 40 \\
\hline 7. & Laporan Operasi & 31 & 34 \\
\hline 8. & Tindakan Operasi & 39 & 26 \\
\hline 9. & Kode Tindakan ICD-9-CM & 0 & 65 \\
\hline 10. & Lembar Informed Concent & 30 & 35 \\
\hline & $\quad$ Rata-rata & 29,6 & 35,4 \\
\hline
\end{tabular}

Berdasarkan tabel 2, hasil kelengkapan pengisisan lembar ringkas masuk dan keluar sebanyak 28 dan hasil ketidaklengkapannya yaitu 37. Kelengkapan pengisian pada diagnosa masuk sebanyak 65 dan hasil ketidaklengkapannya yaitu 0 (nol). Kelengkapan pengisian pada diagnosa utama sebanyak 25 dan hasil ketidaklengkapannya yaitu 40. Kelengkapan pengisisan pada kode ICD-10 sebanyak 20 
dan hasil ketidaklengkapannya yaitu 45. Kelengkapan pengisian pada lembar ringkasan keperawatan sebanyak 33 dan hasil ketidaklengkapannya yaitu 32. Kelengkapan pengisian pada laporan anastesi sebanyak 25 dan hasil ketidaklengkapannya yaitu 40 . Kelengkapan pengisian pada lembar laporan operasi sebanyak 31 dan hasil ketidaklengkapannya yaitu 34. Kelengkapan pengisian pada tindakan operasi sebanyak 39 dan hasil ketidaklengkapannya yaitu 26 . Kelengkapan pengisian pada kode tindakan ICD-9-CM berjumlah 0 (nol) dan hasil ketidaklengkapannya yaitu 65. Kelengkapan pengisian pada lembar informed concent berjumlah 30 dan hasil ketidaklengkapannya yaitu 35. Dari hasil rata-rata yang didapatkan pada kelengkapan di atas berjumlah 25,6 dan ketidaklengkapannya berjumlah 35,4.

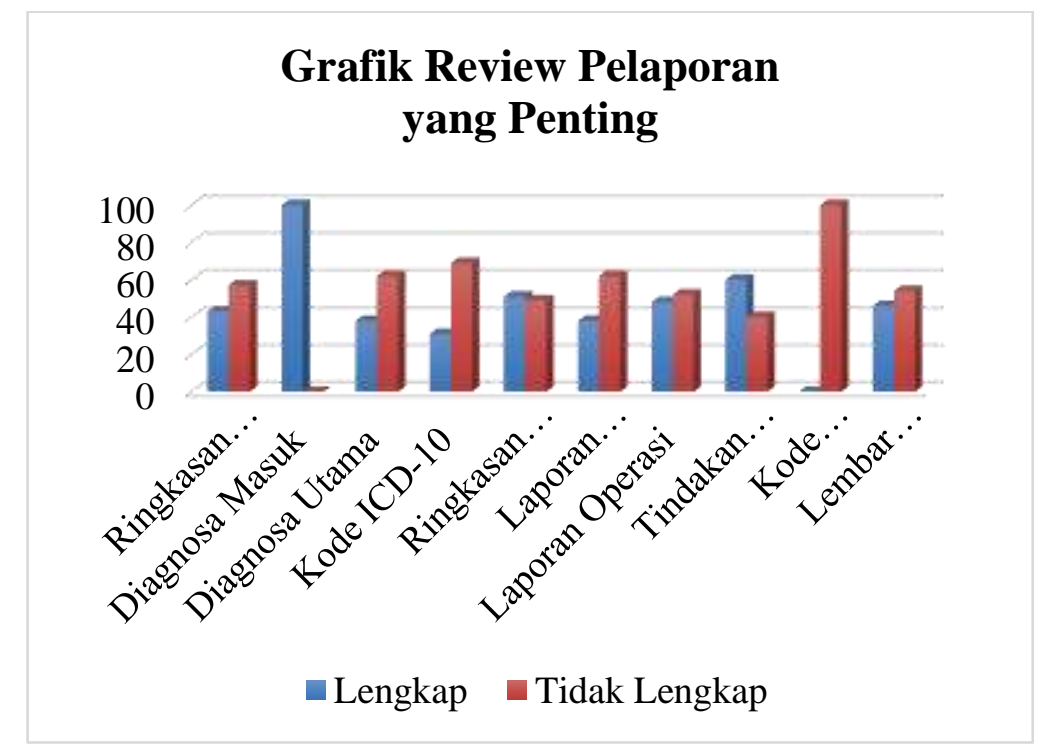

Gambar 2. Grafik Review Pelaporan yang Penting

Berdasarkan gambar 2, grafik diatas bahwa ditemukan hasil persentase pada review pelaporan yang penting dengan persentase kelengkapan pengisian pada lembar ringkas masuk \& keluar yaitu $43 \%$ dan persentase ketidaklengkapannya yaitu $57 \%$. Persentase kelengkapan pengisian pada diagnosa masuk yaitu $100 \%$ dan persentase ketidaklengkapannya yaitu $0 \%$. Persentase kelengkapan pengisian pada diagnosa utama yaitu $38 \%$ dan persentase ketidaklengkapannya yaitu $62 \%$. Persentase kelengkapan pengisian pada kode ICD-10 yaitu 31\% dan persentase ketidaklengkapannya yaitu $69 \%$. Persentase kelengkapan pengisian pada lembar ringkasan keperawatan yaitu $51 \%$ dan persentase ketidaklengkapannya yaitu $49 \%$. Persentase kelengkapan pengisian pada lembar laporan anastesi yaitu 38\% dan persentase ketidaklengkapannya yaitu $62 \%$. Persentase kelengkapan pengisian pada laporan operasi yaitu $48 \%$ dan persentase ketidaklengkapannya yaitu 52\%. Persentase kelengkapan pengisian pada tindakan operasi yaitu $60 \%$ dan persentase ketidaklengkapannya yaitu $40 \%$. Persentase kelengkapan pengisian pada kode tindakan ICD-9-CM yaitu 0\% dan persentase ketidaklengkapannya yaitu $100 \%$. Persentase kelengkapan pengisian pada lembar informed concent yaitu $46 \%$ dan ketidaklengkapannya yaitu $54 \%$.

Hasil grafik diatas bahwa persentase belum $100 \%$ untuk memenuhi standar pelayanan minimal di rumah sakit.

\section{Review Autentifikasi}

Kriteria yang dinilai pada review autentifikasi yaitu nama DPJP (Dokter Penanggung Jawab Pasien) dan tanda tangan DPJP. Setelah dokumen rekam medis di 
analisis, selanjutnya hasil ditabulasi berdasarkan rumus tabulasi yang sudah ditentukan. Adapun hasil perhitungan pada review autentifikasi sebagai berikut :

Tabel 3. Review Autentifikasi

\begin{tabular}{cccc}
\hline \multirow{2}{*}{ No. } & \multirow{2}{*}{ Kriteria } & \multicolumn{2}{c}{ Kelengkapan } \\
\cline { 3 - 4 } & & L & TL \\
\hline 1. & Nama DPJP & 45 & 20 \\
\hline 2. & Tanda Tangan DPJP & 53 & 12 \\
\hline & Rata-rata & 49 & 16 \\
\hline
\end{tabular}

Berdasarkan tabel 3, hasil kelengkapan pengisian pada nama DPJP sebanyak 45 dokumen dan hasil ketidaklengkapannya yaitu 20 dokumen. Kelengkapan pengisian pada tanda tangan DPJP sebanyak 53 dokumen dan hasil ketidaklengkapannya yaitu 12 dokumen. Hasil rata-rata yang didapatkan pada kelengkapan di atas berjumlah 49 dokumen dan ketidaklengkapannya berjumlah 16 dokumen.

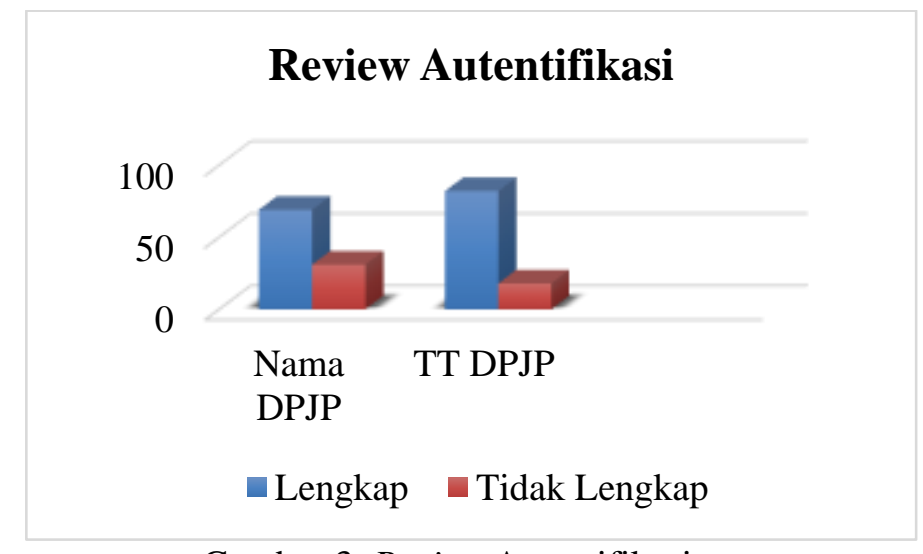

Gambar 3. Review Autentifikasi

Berdasarkan gambar 3, grafik diatas bahwa ditemukan hasil persentase pada review autentifikasi dengan persentase kelengkapan pengisian pada nama DPJP yaitu $69 \%$ dan persentase ketidaklengkapannya yaitu $31 \%$. Persentase kelengkapan pengisian pada tanda tangan DPJP yaitu $84 \%$ dan ketidaklengkapannya yaitu $18 \%$.

Hasil grafik diatas bahwa persentase belum $100 \%$ untuk memenuhi standar pelayanan minimal di rumah sakit.

\section{Review Pendokumentasi}

Kriteria yang dinilai pada review pendokumentasian yaitu tidak adanya tipe-x, tidak adanya coretan, tidak adanya bagian kosong, perbaikan kesalahan disertai tanda tangan. Setelah dokumen rekam medis di analisis, selanjutnya hasil ditabulasi berdasarkan rumus tabulasi yang sudah ditentukan. Adapun hasil perhitungan pada review pendokumentasian sebagai berikut : 
Tabel 4. Review Pendokumentasi

\begin{tabular}{|c|c|c|c|}
\hline \multirow{2}{*}{ No. } & \multirow{2}{*}{ Kriteria } & \multicolumn{2}{|c|}{ Kelengkapan } \\
\hline & & $\mathbf{L}$ & TL \\
\hline 1. & Tidak ada Tipe- $x$ & 65 & 0 \\
\hline 2. & Tidak ada Coretan & 23 & 42 \\
\hline 3. & Tidak ada Bagian Kosong & 20 & 45 \\
\hline 4. & Perbaikan Kesalahan & 56 & 9 \\
\hline & Rata-rata & 41 & 24 \\
\hline
\end{tabular}

Berdasarkan tabel 4, hasil kelengkapan pengisian pada point tidak ada tipe-x yaitu 65 dan ketidaklengkapannya yaitu 0 . Kelengkapan pengisian pada point tidak ada coretan sebanyak 23 dokumen dan ketidaklengkapannya yaitu 42. Kelengkapan pengisian pada point tidak ada bagian kosong sebanyak 20 dan ketidaklengkapannya yaitu 45. Kelengkapan pengisian pada point perbaikan kesalahan sebanyak 56 dan ketidaklengkapannya yaitu 9 dokumen.

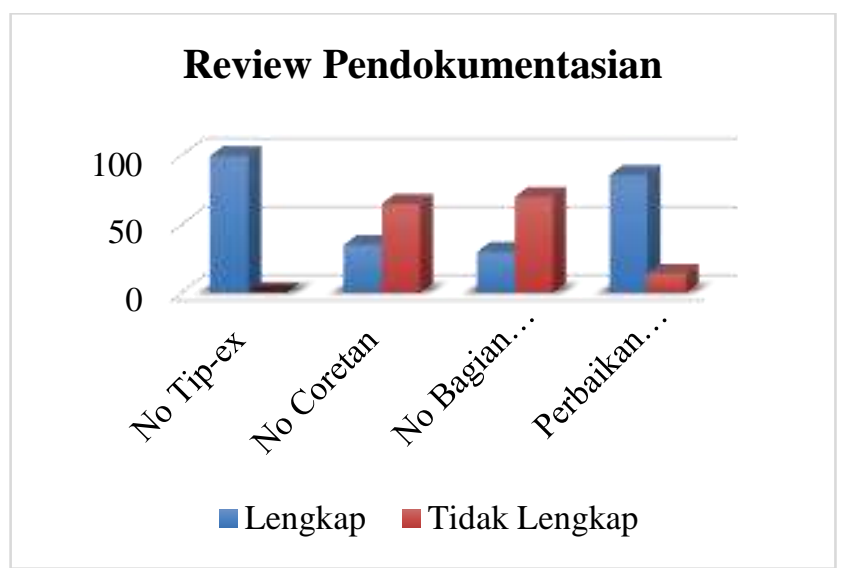

Gambar 4. review Pendokumentasian

Berdasarkan gambar 4, grafik diatas bahwa ditemukan hasil persentase pada review pendokumentasian dengan persentase kelengkapan pengisian pada point tidak ada tipe- $x$ yaitu $100 \%$ dan persentase ketidaklengkapannya yaitu $0 \%$. Persentase kelengkapan pengisian pada point tidak ada coretan yaitu 35\% dan persentase ketidaklengkapannya yaitu $65 \%$. Persentase kelengkapan pengisian pada point tidak ada bagian kosong yaitu $30 \%$ dan persentase ketidaklengkpannya yaitu $70 \%$. Persentase kelengkapan pengisian pada point perbaikan kesalahan yaitu $86 \%$ dan persentase ketidaklengkapannya yaitu $14 \%$.

Hasil grafik diatas bahwa persentase belum $100 \%$ untuk memenuhi standar pelayanan minimal di rumah sakit.

\section{B. Pembahasan}

Hasil yang telah ditetapkan bahwa jumlah persentase kelengkapan tertinggi pada pengisian identifikasi pasien dengan nomor rekam medis berjumlah 40 dokumen dengan hasil (63\%). Persentase terendah pada pengisian nama pasien berjumlah 39 dokumen dengan hasil (60\%). Setiap pasien memiliki formulir rekam medis yang berisikan identitas seperti nama dan nomor rekam medis. Jika ada dokumen rekam medis ditemukan tanpa identitas harus segera di analisis dan di review untuk menemukan milik siapa lembar tersebut (Pengisian \& Alfira, 2018). 
Kelengkapan pengisian pada identifikasi pasien rawat inap kasus bedah di Rumah Sakit X Bandung belum lengkap 100\%, dikarnakan masih sangat banyak dokumen rekam medis yang harus dilengkapi oleh petugas yang bertanggung jawab dokter ataupun perawat. dan hasil penelitian yang di dapatkan ada beberapa formulir yang identitasnya tidak lengkap ditemukan pada beberapa lembar rekam medis yaitu lembar ringkasan keperawatan. Di rumah sakit ini identitas pasien pada lembar dalam dokumen dilengkapi dengan label yang di print, karna keterbatasan label maka ada beberapa yang tidak didapati label tersebut atau saat perawat menempelkannya ada lembar yang terlewat.

Pembahasan diatas belum sesuai dengan keputusan menteri kesehatan Republik Indonesia Nomor 129/MENKES/SK/II/2018 tentang Standar Pelayanan Minimal Rumah Sakit dimana kelengkapan pengisian rekam medis 24 jam setelah selesai pelayanan.

\section{Kelengkapan Pengisian Pelaporan Penting}

Hasil analisis yang telah ditetapkan bahwa jumlah persentase kelengkapan tertinggi pada pengisian Pelaporan penting pasien rawat inap kasus bedah yaitu terdapat pada diagnosa masuk berjumlah 65 dokumen dengan hasil (100\%). Persentase terendah terdapat pada kode tindakan ICD-9-CM berjumlah 0 (nol) dokumen dengan hasil (0\%).

Penjelasan dari hasil di atas bahwa diagnosa masuk lengkap, karena setiap pasien yang akan di rawat inap harus ada keterangan diagnosa masuk. Kode tindakan tidak ada satu pun yang terisi pada lembar rekam medis dan perlu diketahui bahwa penulisan kode tindakan itu sangat penting. Faktor yang menyebabkan terjadinya ketidak lengkapan atau terlewatnya beberapa lembar saat pencatatan pada formulir penting adalah karna keterbatasan waktu dokter sehingga waktu yang digunakan untuk mengisi dokumen rekam medis sangat terbatas dan kurang.

Rekam medis sangat bernilai penting karena jika terdapat diagnosa yang tidak benar ataupun tidak lengkap maka secara otomatis kode penyakitnya pun tidak tepat, hal tersebut dapat memengaruhi terhadap pengisian indeks penyakit dan laporan rumah sakit (Ri, 2006). Pengisian pelaporan harus selalu diperhatikan kelengkapannya, karena dokumen tersebut bisa menjadi suatu bukti tertulis dalam mendukung aspek hukum rekam medis dan untuk melindungi pasien atas setiap tindakan yang dilakukan tidak dikategorikan sebagai malpraktek. Jika dokumen rekam medis tidak terisi dengan lengkap maka akan dikenakan sanksi administrasi yang dapat mengakibatkan kerugian bagi pasien, baik itu material maupun non material (Permenkes RI, 2008).

\section{Kelengkapan Pengisian Autentifikasi}

Hasil analisis yang telah ditetapkan bahwa jumlah persentase kelengkapan tertinggi pada pengisian autentifikasi pasien rawat inap kasus bedah yaitu terdapat pada tanda tangan DPJP (Dokter Penanggung Jawab Pasien) berjumlah 53 dokumen dengan hasil $(82 \%)$. Persentase terendah terdapat pada nama DPJP berjumlah 45 dokumen dengan hasil (69\%).

Hasil menunjukan bahwa masih ada saja dokter yang hanya menandatangani lembar rekam medis tanpa menyantumkam nama dokter dengan gelar profesional. hal Tersebut dapat berakibat pada perawatan, pemerikasaan dan pengobatan yang sudah dilakukan lalu tidak bisa dipertanggung jawabkan oleh dokter tersebut dan bisa mempersulit petugas Rekam medis dalam menentukan dokter yang bertanggung jawab terhadap pasien pada saat menganalisisnya.

Peraturan Menteri Kesehatan Rebublik Indonesia Nomor 269/MENKES/PER/III/2008 pada pasal 5 ayat (4), setiap penulisan atau pencatatan dalam rekam medis harus disertai nama, waktu dan tanda tangan dokter, dokter gigi atau tenaga kesehatan tertentu lainnya yang memberikan pelayanan kesehatan secara langsung. Pada pencatatan pengisian setiap lembar dokumen rekam medis harus jelas penanggung jawabnya. Review autentifikasi ini dapat berupa tanda tangan, gelar profesional, nama atau cap (stempel) (Pengisian \& Alfira, 2018). 


\section{Kelengkapan Pengisian Pendokumantasian}

Hasil analisis yang telah ditetapkan bahwa jumlah persentase kelengkapan tertinggi pada pengisian pendokumentasian pasien rawat inap kasus bedah yaitu terdapat pada point tidak ada tipe- $x$ sebesar 65 dokumen dengan hasil (100\%). Persentase terendah terdapat pada point tidak ada bagian yang kosong sebesar 20 dokumen dengan hasil (30\%).

Hasil menunjukan bahwa dokter maupun perawat tidak memakai tipe- $x$ sama sekali dalam pembenaran kesalahan penulisan di formulir rekam medis dan ada beberapa dokter atau perawat yang mencoret pada tulisan yang salah beberapa kali dan tidak menyertai tanda tangan.Kesalahan pada pembetulan tulisan dapat membuat data yang ditulis menjadi tidak sah atau tidak benar untuk dijadikan bukti tindakan yang telah dokter lakukan kepada pasien.

Menurut Permenkes Nomor 269/MENKES/PER/III/2008 pada pasal 5, ayat (5), dijelaskan jika terjadi kesalahan dalam melakukan pencatatan pada formulir rekam medis dapat dilakukakan pembetulan dengan cara satu kali pencoretan tanpa menghilangkan catatan yang dibenarkan dan disertai Tanda tangan dokter, dokter gigi atau tenaga kesehatan tertentu yang bersangkutan (Permenkes, 2016).

\section{KESIMPULAN}

Berdasarkan hasil dari penelitian analisis dokumen rekam medis rawat inap kasus bedah yang dilakukan di Rumah Sakit X Bandung, maka dapat disimpulkan bahwa dokumen rekam medis yang tidak lengkap yaitu ketika dokumen dikembalikan ke unit rekam medis kemudian dokumen tersebut di KLPCM dan dianalisis kelengkapannya. setelah di KLPCM dan dianalisa, dokumen rekam medis yang tidak lengkap akan dikembalikan kepada unit rawat inap.

Berdasarkan hasil alalisa 65 dokumen rekam medis rawat inap kasus bedah didapatkkan hasil persentase kelengkapan pada komponen identifikasi pasien yaitu $61 \%$, Catatan yang penting $45 \%$, Autentifikasi penulis $75 \%$ dan pendokumentasian $63 \%$. Adapun hasil presentase ketidaklengkapan identifikasi pasien 39\%, Catatan yang penting $55 \%$, Autentifikasi penulis $25 \%$ dan pendokumentasian $37 \%$.

Maka persentase kelengkapan tertinggi terdapat pada komponen Autentifikasi penulis yaitu $75 \%$, dan presentase kelengkapan terendah terdapat pada komponen catatan yang penting yaitu $45 \%$. Begitu pula sebaliknya persentase ketidaklengkapan tertinggi terdapat pada komponen catatan yang penting yaitu $65 \%$, dan persentase ketidaklengkapan terendah terdapat pada komponen autentifikasi penulis yaitu $25 \%$.

Faktor penyebab ketidaklengkapan pengisian dokumen rekam medis rawat inap kasus bedah yaitu pengisian resume medis kurang disosialisasikan, dokter sibuk dan mempunyai waktu yang padat, dokter kurang patuh dalam pencatatan resume medis, sehingga belum maksimal dan menyebabkan banyaknya dokumen rekam medis yang tidak lengkap. 


\section{BIBLIOGRAFI}

Arini, L., Sulindawati, N. L. G. E., Herawati, N. T., \& AK, S. E. (2015). Analisis Pengendalian Intern Terhadap Persediaan Obat Untuk Pasien Pengguna BPJS (Badan Penyelenggara Jaminan Sosial) Kesehatan di RSUD (Rumah Sakit Umum Daerah) Kabupaten Buleleng. JIMAT (Jurnal Ilmiah Mahasiswa Akuntansi) Undiksha, 3(1).

Hatta, G. R. (2013). Pedoman Manajemen Informasi Kesehatan Di Sarana Pelayanan Kesehatan. UI-Press.

Munawaroh, E., Fatimah, D. D. S., \& Supriatna, A. D. (2013). Perancangan aplikasi rekam medis klinik bersalin baiturrahman menggunakan metode object oriented. Jurnal Algoritma, 10(2), 167-176.

Pengisian, A. K. K., \& ALFIRA, N. (2018). Literatur Review.

Permenkes, R. I. (2008a). No 269/Menkes/Per/III/2008 tentang Rekam Medis. Jakarta: Menteri Kesehatan Reupublik Indonesia.

Permenkes, R. I. (2008b). Permenkes Nomor 269/Menkes/Per/III/2008 Tentang Rekam Medis. Jakarta: Kemenkes RI.

Permenkes, R. I. (2016). Peraturan Menteri Kesehatan Republik Indonesia Nomor 76 Tahun 2016 Tentang Pedoman Indonesian Case Base Groups (INA-CBG) Dalam Pelaksanaan Jaminan Kesehatan Nasional. Jakarta, Indonesia.

Permenkes RI. (2008). permenkes ri 269/MENKES/PER/III/2008. In Permenkes Ri No 269/Menkes/Per/Iii/2008 (Vol. 2008, p. 7).

Ri, D. (2006). Pedoman Penyelenggaraan dan Prosedur Rekam Medis Rumah Sakit di Indonesia. Jakarta: Depkes RI.

Septiany, P. D. (2020). Analisis Pengisian Odontogram Rekam Medis di Rumah Sakit Gigi dan Mulut (Rsgm) Universitas Jember.

Sugiyono. (2016). Metode Penelitian Kuantitatif, Kualitatif dan $R \& D$. PT Alfabet.

Susanto, E., \& Windari, A. (2017). Studi Deskriptif Kelengkapan Dokumen Rekam Medis Rawat Inap pada Kasus Bedah Orthopedy di RSUD Kota Semarang. Jurnal Manajemen Informasi Kesehatan Indonesia (JMIKI), 5(2), 175-180.

UU No. 29 Tahun 2004 Tentang Praktik Kedokteran, (2004).

(C) 2021 by the authors. Submitted for possible open access publication under the terms and conditions of the Creative Commons Attribution (CC BY SA) license (https://creativecommons.org/licenses/by-sa/4.0/). 